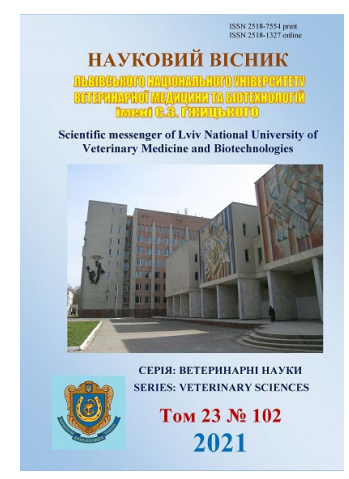

Науковий вісник Яьвівського національного університету ветеринарної медицини та біотехнологій імені С.3. Гжицького. Серія: Ветеринарні науки

\author{
Scientific Messenger of Lviv National University \\ of Veterinary Medicine and Biotechnologies. \\ Series: Veterinary sciences
}

doi: $10.32718 /$ nvlvet10209 https://nvlvet.com.ua/index.php/journal

UDC 591.5:378:636.09

\title{
Ethology and Zoopsychology in the system of training a doctor of veterinary medicine
}

I. O. Zhukova, O. M. Bobrytska, I. O. Kostiuk, L. A. Vodopyanova, K. D. Yugai, S. L. Antipin, O. S. Kochevenko

\section{Kharkiv State Zooveterinary Academy, Kharkiv, Ukraine}

Article info

Received 15.03.2021

Received in revised form 19.04.2021

Accepted 20.04.2021

Kharkiv state zooveterinary academy, Mala Danilivka, Dergachi district, Kharkiv region, 62341, Ukraine.

Tel.: +38-095-773-65-26

E-mail:patfiz@zoovet.kh.ua
Zhukova, I. O., Bobrytska, O. M., Kostiuk, I. O., Vodopyanova, L. A., Yugai, K. D., Antipin, S. L., \& Kochevenko, O. S. (2021). Ethology and Zoopsychology in the system of training a doctor of veterinary medicine. Scientific Messenger of Lviv National University of Veterinary Medicine and Biotechnologies. Series: Veterinary sciences, 23(102), 60-65. doi: 10.32718/nvlvet10209

The authors have analyzed and summarized data sources regarding the necessary teaching of ethology and zoopsychology for students of the faculties of veterinary medicine. Ethology and zoopsychology is a compulsory subject for almost all educational institutions of this profile in Europe and the USA. In Ukraine these subjects are constant at the studying programs of the psychology faculties of the different universities, which prepare the specialists of reworking agrifood, the specialists of horse breeding, the felinologiests and others, but these ones are not consist a part of the preparing programs for the vet medicine students. Nevertheless, for a treatment and prevention it needs to understand the animal behavior features of and to might find out the approaches, to use humane methods without any animal damages and suffering. Ethology it is science, which studies the animal behavior from the biology side but Zoopsichology is close to both biological and psychological sciences and investigate not only natural behavior, but also the animal psyche. Therefore, until today there is a lot of unknown and obscure things into natural behavioral processes so the new explorations raise the curtain over the issues to understand animal and find access to its. It is only conditionally might be dividing the biological and psychological aspects of behavior because of it is impossible to connect they together without take into consideration the psyche factors. The animal psyche is necessary component of the ontho- and phylogenesis which is regulates the relationships between an organism and the environment. The tasks of Zoopsychology are studying of the formation of the psyche processes in animal during the ontogenesis, an origin of the psyche and its development, but Ethology tasks are - the stages of the ontho- and phylogenetical development of the behavior, determine its importance as a development factor, studying of the individual or population adaptation of the animals. The main respect comes to species-specific (instinctive) components of behavior. Ethological analysis is based on the study of biological methods of holistic behavioral act. Particular attention is paid to biological (etological) mechanisms of behavioral acts, the relationship between species and other taxa of animals on these grounds. Ethology studies the changes of the animal behavior in comparison with norms during emergency too. Its achievements are used in animal husbandry and other sectors of the economy, as well as in the development of scientific bases for keeping animals in captivity.

Key words: behavior, ethology, zoopsychology, veterinarian.

\section{Етологія і зоопсихологія в системі підготовки лікаря ветеринарної медицини}

\author{
I. О. Жукова, О. М. Бобрицька, І. О. Костюк, Л. А. Водоп’янова, К. Д. Югай, С. Л. Антіпін, \\ О. С. Кочевенко
}

Харківська державна зооветеринарна академія, м. Харків, Украӥна

У даній статті авторами проаналізовано і узагальнено літературні дані щзодо необхідності викладання студентам факультетів ветеринарної медицини навчальної дисципліни “Етологія з основами зоопсихологї”. Етологія $i$ зоопсихологія $\epsilon$ 
обов'язковими предметами майже в усіх навчальних закладах изього профілю Європи $і$ Сполучених Штатів Америки. В Україні изі науки є обов'язковими в програмі навчання на факультетах психології різних університетів, для підготовки спеціалістівтехнологів переробки продуктів тваринництва, кінологів, фелінологів та інших, але в програму підготовки лікарів ветеринарної медицини не входять, тимчасом як для циих спеціалістів вони конче необхідні, оскільки тварини не можуть вербально повідомити про свої проблеми і потреби, а для лікування і профілактики захворювань потрібно розуміти особливості їхньої поведінки і вміти знайти до них підхід, а також застосовувати гуманні методи, щуоб не нанести тварині шкоди і страждань. Етологія - наука, яка вивчає поведінку тварини з біологічного боку, а зоопсихологія є суміжною для біологічної та психологічної наук дисиипліною і досліджує не тільки поведінку тварин, а й їхю психіку. Оскільки до нинішнього часу є ще дуже багато невивченого і незрозумілого в складних природних прочесах поведінки, нові сучасні дослідження підіймають завісу над питаннями, як зрозуміти тварину $і$ знайти до неї підхід. Біологічні та психічні аспекти поведінки тварин можна розділити лише умовно, адже без урахування психічних факторів неможливо охопити всі ї̈ аспекти. Психіка тварин - необхідний компонент онто- $і$ філогенезу, який регулює відносини організму з середовищем. Завданням зоопсихології є вивчення формування психічних процесів у тварин в онтогенезі, походження психіки та ї̈ розвитку в процесі еволюції, а етології-етапи філо- $і$ онтогенетичного розвитку поведінки, виявлення значення ї̈ як чинника еволючії, індивідуальної і популяційної адаптацї тварин. Основна увага приділяється видотиповим (інстинктивним) компонентам поведінки. Етологічний аналіз грунтується на дослідженні біологічними методами иілісного поведінкового акту. Особлива увага приділяється біологічним (екологічним) механізмам поведінкових актів, зв'язку між видами та іншими таксонами тварин за циим ознаками. Етологія вивчає також відхилення поведінки тварин від норми в екстремальних ситуаціях. Ї̈ досягнення знаходять застосування в тваринництві та інших галузях народного господарства, а також при розробці наукових основ утримання тварин в неволі.

Ключові слова: поведінка, етологія, зоопсихологія, лікар ветеринарної медищини.

\section{Вступ}

Термін етологія (грец. $\tilde{\eta} \theta$ о (ethos) - звичай, характер), введений у 1859 році французьким зоологом Ізідором Жоффруа Сент-Ілером, характеризує дисципліну, що вивчає поведінку тварин. Засновником науки $є$ лауреат Нобелевської премії Конрад Лоренц, який назвав етологію “морфологією поведінки тварини”.

В Україні відомим етологом був професор Харківського університету ім. В. Н. Каразіна А. П. Крапівний, який досліджував міжвидові відносини тварин та біоекологічні аспекти зоопсихології, філософський, математичний аналіз складної поведінки тварин та ін. (Slyusar et al., 2017).

Зоопсихоло́гія ж є суміжною для біологічної та психологічної наук дисципліною, яка досліджує не тільки поведінку тварин, а й їх психіку (від дав.-гр.

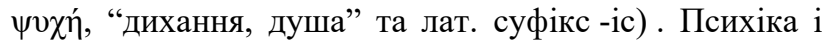
поведінка тварин утворюють безпосередню єдність, тому що вони не мають здатності свідомо аналізувати ситуацію і їх реакція на будь-які значущі сигнали із зовнішнього середовища проявляється у вигляді рухової реакції. Сучасна зоопсихологія визначає поведінку тварин як сукупність зовнішньої, переважно рухової активності, яка спрямована на встановлення зв'язків організму із середовищем іiі проживання (Leont'yev, 1972, Egerton, 2016).

\section{Результати та їх обговорення}

Зоопсихологія є невід'ємною і важливою частиною психологічних наук. Інтерес до неї помітно виріс в останні роки, особливо в зв'язку з тим, що в цій галузі знань зараз спостерігається велике піднесення дослідницької роботи і творчої думки. Поряд з великим теоретичним значенням зоопсихологічних досліджень все більш розширюється і сфера їхнього практичного використання. Плідна робота дослідників багатьох країн з вивчення поведінки тварин, що охоплює всі зоологічні таксони - від амеби до шимпанзе, привела до значних результатів: в даний час накопи- чено таку велику кількість найцінніших наукових фактів, що не тільки вдалося роз'яснити ряд суттєвих питань зоопсихології, а й довелося внести серйозні поправки в, здавалося б, цілком усталені положення і концепції. Зрозуміло, і понині залишається ще дуже багато невивченого і незрозумілого в процесах поведінки - цих складних природних процесах. Все ж ми можемо зараз краще уявити біологічні передумови i передісторію зародження людської свідомості. Отже, зоопсихологи спрямовують свої зусилля на вивчення психічних аспектів поведінки, етологи - біологічних. Зрозуміло, що ці два аспекти можна розділити лише умовно: адже без урахування психічних факторів неможливо охопити всі біологічні аспекти поведінки. Психіка тварин необхідний компонент онто- і філогенезу, який регулює відносини організму з середовищем (Proster \& Braun 1996; Fabri, 2001; 2003).

Етологія і зоопсихологія викладається майже в усіх навчальних закладах Свропи і Сполучених Штатів Америки. В Україні ці науки є обов'язковими в програмі навчання на факультетах психології різних університетів, для підготовки спеціалістів-технологів переробки продуктів тваринництва, кінологів, фелінологів та інших, але у програму підготовки лікарів ветеринарної медицини не входить, тимчасом як для цих спеціалістів вона конче необхідна, оскільки тварини не можуть вербально повідомити про свої проблеми і потреби, а для лікування і профілактики захворювань потрібно розуміти особливості їх поведінки і вміти знайти до них підхід, а також застосовувати гуманні методи, щоб не нанести тварині шкоди i страждань (Zakon Ukrayiny № 3447-IV, 2006; Pan'ko, 2006).

Завданням зоопсихології $є$ вивчення формування психічних процесів у тварин в онтогенезі, походження психіки та іiі розвитку в процесі еволюції, біологічних передумов і передісторії зародження людської свідомості, а етології - етапи філо- і онтогенетичного розвитку поведінки тварин, виявлення значення поведінки як чинника їх еволюції, індивідуальної і популяційної адаптації. Основна увага приділяється при цьому видотиповим (інстинктивним) компонентам 
поведінки. Етологічний аналіз грунтується на дослідженні біологічними методами цілісного поведінкового акту. Видотипові пози і рух описуються у вигляді “етограм” (систематизованих “каталогів" рухової активності видів); шляхом спостережень і експериментів встановлюється функціональне значення цих компонентів, здійснюється кількісний та якісний аналіз зовнішніх і внутрішніх факторів поведінки. Особлива увага приділяється біологічним (екологічним) механізмам поведінкових актів, зв’язку між видами та іншими таксонами тварин за ознаками поведінки. Етологія вивчає також відхилення поведінки тварин від норми в екстремальних ситуаціях. Її досягнення знаходять застосування в тваринництві та інших галузях народного господарства, а також при розробці наукових основ утримання тварин в неволі (Fabri, 2001; 2003; Zorina \& Poletayeva, 2003; Filonenko \& Shevtsiv, 2019; Janmaat et al., 2021).

У етології і зоопсихології застосовують багато методів досліджень, такі як зображення (малюнки, фотографіï), словесний опис, хронометраж, тобто етограма, а також спостереження, експеримент, абсолютний облік тварин, мічення, “проблемної клітки”, “лабіринту”, генетики поведінки, екологічні та ін. (Southwood \& Henderson, 2000).

Поведінка - це спрямовані зовні дії організму у відповідь на зовнішні або внутрішні стимули, які змінюють взаємини організму з навколишнім середовищем і сприяють збереженню виду. Реакції можуть бути різними: від найпростіших рухів на світло до шлюбних ігор і захисту території.

Для ефективної роботи ветеринарного лікаря необхідно чітко знати основні (вроджені й набуті) форми поведінки тварин, такі як таксиси, інстинкти i рефлекси.

Фізіологічна поведінка - це вроджена, соматична реакція типу таксисів (вроджених, генетично фіксованих реакцій тварин на певні агенти середовища, які відіграють роль напрямних ключових подразників), які відповідають на напрямні ключові подразники і змінюють вектор перебігу інстинктивної реакції, але не здатні обумовлювати іiі початок або кінець.

Крім таксисів, існують кінези, за яких не відбувається орієнтація тіла тварини щодо подразника. В даному випадку подразники викликають або зміну швидкості пересування тварини, або змінюється частота поворотів тіла. При цьому відбувається зміна положення тварини щодо подразника, але орієнтація його тіла залишається незмінною

Одним із головних аспектів, які формують поведінку тварин і їх виживання, $є$ інстинкти - вроджені, генетично закодовані іiі елементи, які реалізуються без попереднього навчання. Вони є характерними видовими рисами, виникають в процесі еволюції і $є$ адаптацією до тих особливостей середовища, які повільно змінювалися і були оптимальними для виду. Сталість інстинктивних компонентів поведінки забезпечує стабільність дії найбільш важливих життєвих функцій незалежно від випадкових змін середовища, в яких може опинитися представник виду.
Вродженні (інстинктивні) компоненти поведінки формують весь еволюційний шлях, пройдений видом. Це найцінніше, що придбано в ході філогенезу для виживання особини. Такого роду генетично закодовані програми поведінки передаються 3 покоління в покоління. Ось чому їхня головна властивість - стійкість, стабільність. Вони не повинні, а тому й не здатні легко змінюватися під впливом випадкових зовнішніх впливів.

Прикладом таких вроджених реакцій поведінки можуть служити створені бджолами геометрично правильні стільники, реакція ще сліпого зозуленяти при викиданні яєць і пташенят з гнізда ментора, споруда хатки бобреням, вихованим в ізоляції від дорослих бобрів, смоктання молочної залози у ссавців та ін. У всіх перерахованих прикладах мова йде виключно про вроджені, спадкові поведінкові реакції. Тут поки що відсутні елементи психічного відображення, але розвиток інстинктивної поведінки готує все необхідне для стрибка, що веде до психічного відображення. Інстинкти можуть бути як жорсткими, консервативними, так і більш рухливими, лабільними, тобто допускається відхилення від генетично заданої програми (Akimushkin, 1985; Vagner, 2002).

Найбільш консервативними $є$ ті інстинкти, які пов'язані з шлюбними ритуалами, підбором пар, спарюванням та іншими формами поведінки в період розмноження. Довести відсутність психічного відображення в даному випадку не важко: у птахів і ссавців “нетипова” поведінка самця або самки унеможливлює утворення пари, але й у класичних формах шлюбної поведінки $\epsilon$ варіації, які наштовхують на думку, що розмноження тварин не такий примітивний процес, яким би міг видатися на перший погляд. Прикладом можуть слугувати випадки, коли готові вже до спарювання самки вибирають самця і якщо він їм не підходить, вони їм відмовляють

Поведінка, пов'язана з розмноженням, є головним фактором, що сприяє еволюційному успіху організмів і піддається впливу багатьох еволюційних сил, включаючи природний та статевий відбір, та сексуальні конфлікти. Успішне розмноження включає цілий ряд способів поведінки, від пошуку відповідного партнера, залицяння та копуляції до виведення потомства (Vagner, 2001; Anholt et al., 2020).

За даними більшості вчених, в статевій поведінці, особливо у нижчих тварин, велику роль відіграють ключові подразники (релізери), яких існує безліч і які залежно від ситуації можуть викликати або зближення статевих партнерів, або бійку. Дія релізера безпосередньо залежить від рівноваги сукупності складових його подразників.

Прояви залицяння - це поведінка, спрямована на полегшення залучення та спаровування 3 протилежною статтю, i дуже поширена у світі тварин. Більшість проявів залицянь $є$ мультимодальними, це означає, що вони складаються з супутніх сигналів, які відбуваються в різних сенсорних модульностях. Наприклад, у качок ритуал залицяння проявляється у рухах догляду за оперенням, а в поведінці чайок під час шлюбних ігор простежується конфлікт між праг- 
ненням напасти на партнера і сховатися від нього. Іноді в поведінці можна помітити прояв різнорідних елементів одночасно. У всякому разі в процесі еволюції будь-які рухи зазнали значних змін і перетворилися в релізери. Найчастіше зміни йшли в напрямку посилення ефекту, що може полягати в їх багаторазовому повторенні, а також збільшення швидкості їхнього виконання (Vladimirova, 2010; Tinbergen, 2012; Owen et al., 2017; Mitoyen et al., 2019).

Для синхронізації статевої поведінки необхідно, щоб самець і самка були готові до розмноження в один і той же час. Така синхронізація досягається за допомогою гормонів і залежить від пори року та довжини світлового дня, але остаточна “підгонка" відбувається тільки при зустрічі самця і самки, що було доведено низкою лабораторних дослідів. У багатьох видів тварин синхронізація статевої поведінки розвинена на дуже високому рівні. Статева диференціація, розвиток та функції репродуктивної системи значною мірою залежать від зовнішніх і внутрішніх факторів, особливо стероїдних гормонів. Вплив на організм естрогенних та антиандрогенних ендокринних хімічних речовин (ЕDC) асоціюється 3 репродуктивною дисфункцією в дорослому віці (Нo et al., 2017).

Наступний важливий компонент поведінки у світі тварин - це домінування та ієрархія. Ієрархія в біології - система підпорядкування-домінування в агрегації соціальних тварин. Вивчаючи тварин, що живуть групами, таких як вовки, мавпи і навіть курки, вчені виявили у тих ієрархію домінування. Це класифікація групи особин за їхнім рангом у соціумі, за владою або престижем. Біосоціальні системи теоретично можуть бути побудовані по принципах егалітаризму - тобто повної рівності всіх особин в плані розподілу ресурсів і управління біосоціальною системою. Фактично переважна більшість біосоціальних систем включають ту або іншу міру нерівності особин, так що індивіди, які входять в систему, розрізняються за біосоціальними рангами. Сукупність цих рангів і позначається як ієрархія. Сильні завжди перебувають в більш привілейованому становищі перед слабкими. Така система дозволяє мінімізувати шкоду, які особини можуть завдати один одному в боротьбі за права.

Альфа - головні, ватажки, переважно найбільші й сильніші, але не завжди агресивніші особини в зграї. Їм зазвичай дістаються всі самки і кращі шматки їжі. На них накладаються обов'язки управління зграєю i підтримки ієрархії. Бета-особини перебувають на “других ролях”, як правило - це молоді й недосвідчені тварини. У випадку, якщо альфа ослабне, вони займають його місце. Омега - на найнижчому щаблі ієрархічної драбини, вони найслабші, не виявляють ініціативи, шансів парування з самкою у них немає й іноді їх можуть вбити сильніші тварини (Oleskin, 2012; Kubinyi \& Wallis, 2019).

У контакті зі зграйними тваринами (собаки, вовки) ветеринарний лікар повинен чітко знати правила ієрархії для управління твариною в процесі лікувальних або профілактичних заходів для своєї безпеки і оточуючих людей, особливо якщо ця тварина має ознаки лідера зграї.
Будь-яка тварина опиняється під впливом екзогенних i ендогенних чинників, які прямо чи побічно впливають на нервову систему (Savel'yev, 1998). Нервова система визначає форму поведінки, яка реалізується через механічну взаємодію тварини з середовищем. До зовнішніх систем контролю поведінки, які впливають на діяльність живих організмів, належить усе, що оточує тварин, вони дуже чутливі до цих впливів і їхнє життя залежить від будь-яких змін в навколишньому середовищі. Ці дії позначаються на різних аспектах поведінки. Всі зовнішні впливи поділяють на дві групи: 1) абіотичні (фізичні); 2) біотичні (біологічні).

Фізичні фактори - це всі прямі й непрямі впливи неживої природи на поведінку тварин (електромагнітне і сонячне випромінювання, місячна і зоряна активність, пора року, тривалість дня, стан води, повітря, грунту, температура, рельєф місцевості або дна моря, атмосферний тиск або глибина океану, освітленість, радіаційний фон та ін.), що є частиною природного середовища і не створені рослинами, тваринами або людиною.

Однією з найбільш універсальних і стабільних систем контролю, що забезпечують міграцію, є геомагнітне поле Землі. Його сприймають багато тварин: перелітні птахи, риби, що мігрують, деякі види земноводних, рептилій, комах, молюсків і ссавців. Так встановлено, що зональність природного магнітного поля Землі призводить до формування магнітних максимумів і мінімумів на великих ділянках морського дна. Спеціальні дослідження показали, що кити і дельфіни часто викидаються на сушу в зонах перетину берегової лінії смугами магнітних максимумів, а сонячні бурі порушують нічну міграцію співочих птахів (Ferrari, 2017; Vanselow et al., 2017; Bianco et al., 2019). Деякі тварини використовують при міграціях особливості рельєфу місцевості, сонячні орієнтири, візуальну інформацію та сукупність багатьох непрямих ознак, наприклад, орієнтація і хомінг (повернення на територію постійного проживання).

I нарешті, для пізнання і контролю поведінки тварин-пацієнтів ветеринарний лікар повинен знати такий розділ етології, як научіння у тварин, тобто придбання та накопичення тваринами в онтогенезі індивідуального досвіду, вдосконалення і видозміну вродженої (інстинктивної) основи психічної діяльності відповідно до конкретних умов середовища проживання. Навчення - це основна форма набуття досвіду тваринами. Відбувається воно або поступово в повторюваних актах поведінки, або відразу - як відображення. Спрямоване вчення у тварин існує лише в зародковій формі (обстеження нової ситуації, наслідування). У тварин навчення відбувається на базі вроджених інстинктів, структура яких може перебудовуватися в аспекті конкретних умов життя. В ході навчання у тварин розвиваються ті індивідуальномінливі компоненти поведінки, котрі надають їм необхідну для виживання адаптивну гнучкість і варіабельність. В результаті формується єдиний поведінковий акт, що містить як вроджені - видотипові, так і надбані - індивідуально-мінливі компоненти. До най- 
примітивніших форм навчання у тварин належить сенсорно-моторне тренування і звикання до довготривалих або повторюваних зовнішніх подразників. Однією з форм навчення $є$ формування навику, в якому виконавчі операції є досить автоматизованим і позбавленими зайвих компонент; їх повторення і закріплення дозволяє досягти значно кращого пристосування до зовнішнього середовища. Ця форма є навичкою, яка забезпечує вирішення певної біологічної задачі. Зміст навичок визначається характером подоланих при їх формуванні перешкод, досконалість - диференційованістю і генералізованістю сприйняття умов, в яких вони формуються. При дресируванні тварин вироблення навичок відбувається під цілеспрямованим впливом людини відповідно до іiї задумів: систематично підкріплюються (зазвичай їжею) необхідні рухи, поєднувані з сигналами, що подаються дресирувальником, і усуваються (шляхом покарання) небажані дії. Як особлива форма навчання виступає фіксація (Mak-Farlend, 1988).

\section{Висновки}

Отже, із аналізу джерел літератури випливає, що етологія і зоопсихологія є важливими науками у системі підготовки ряду спеціалістів, в тому числі й лікарів ветеринарної медицини, оскільки знання особливостей поведінки і психіки тварин та вміння знаходити з ними контакт потрібні для успішного лікування і профілактики захворювань різної етіології, а для того, щоб не нанести тварині шкоди і страждань - вміння виробляти навички для підбору і застосування гуманних і етичних методів.

\section{References}

Akimushkin, I. (1985). Problemy etologii (tropizmy). M.: "Molodaya gvardiya", 5-10 (in Russian).

Anholt, R. R. H., O'Grad, P., Wolfner, M. F., \& Harbison, S. T. (2020). Evolution of Reproductive Behavior. Genetics, 214(1), 49-73. doi: 10.1534/genetics.119. 302263.

Bianco, G., Ilieva, M., \& Akesson, S. (2019). Magnetic storms disrupt nocturnal migratory activity in songbirds. Biol. Lett., 15. doi: 10.6084/m9.figshare.c.4414691.

Egerton, F. N. (2016). History of Ecological Sciences, Part 56: Ethology until 1973. Bulletin of the Ecological Society of America, 97(1), 31-88. doi: 10.1002/bes2.1219.

Fabri, K. E. (2001). Osnovy zoopsikhologii. M.: UMK "Psikhologiya" (in Russian).

Fabri, K. E. (2003). Osnovy zoopsikhologii: Uchebnik dlya studentov vysshikh F12 uchebnykh zavedeniy, obuchayushchikhsya po spetsial'nostyam "Psikhologiya", "Biologiya", "Zoologiya" i "Fiziologiya". 6-ye izd. M.: UMK "Psikhologiya" (in Russian).

Ferrari, T. E. (2017). Cetacean beachings correlate with geomagnetic disturbances in Earth's magnetosphere: an example of how astronomical changes impact the future of life. Int. J. Astrobiol., 16(2), 163-175 doi: $10.1017 / \mathrm{S} 1473550416000252$.
Filonenko, M., \& Shevtsiv, M. (2019). Zoopsykholohiya z osnovamy etolohiyi. Kyyiv: Tsentr navchal'noyi literatury (in Ukrainian).

Ho, Sh.-M., Cheong, A., Adgent, M. A., Veevers, J., Suen, A. A., Tam, N. N. C., Leung, Y.-K., Jefferson, W. N., Williams, C. J. (2017). Environmental factors, epigenetics, and developmental origin of reproductive disorders. Reprod Toxicol, 68, 85-104. doi: 10.1016/j.reprotox.2016.07.011.

Janmaat, K. R. L., de Guinea, M., Collet, J., Byrne, R. W., Robira, B., van Loon, E., Jang, H., Biro, D., Ramos-Fernández, G., Ross, C., Presotto, A., Allritz, M., Alavi, Sh., \& Van Belle, S. (2021). Using natural travel paths to infer and compare primate cognition in the wild. iScience, 24(4), 102343. doi: 10.1016/j.isci.2021.102343.

Kubinyi, E., \& Wallis, L. J.(2019). Dominance in dogs as rated by owners corresponds to ethologically valid markers of dominance. PeerJ, 7, e6838. doi: $10.7717 /$ peerj.6838.

Leont'yev, A. N. (1972). Problemy razvitiya psikhiki. 3ye izd. M. (in Russian).

Mak-Farlend, D. (1988). Povedeniye zhivotnykh: Psikhobiologiya, etologiya i evolyutsiya. Per. s angl. M.: Mir (in Russian).

Mitoyen, C., Quigley, C., \& Fusani, L. (2019) Evolution and function of multimodal courtship displays. Ethology; 125(8), 503-515. doi: 10.1111/eth.12882.

Oleskin, A. V. (2012). Setevyye struktury v biosistemakh i chelovecheskom sotsiume. Nauchnaya monografiya i uchebnoye posobiye dlya litseyev, kolledzhey i universitetov. M.: Izdatel'stvo URSS (in Russian).

Owen, M. A., Swaisgood, R. R., \& Blumstein, D. T. (2017) Contextual influences on animal decision-making: Significance for behavior-based wildlife conservation and management Affiliations expand. Integr Zool, 12(1), 32-48. doi: 10.1111/1749-4877.12235.

Pan'ko, I. C. (2006). Profesiyna etyka likarya veterynarnoyi medytsyny. Bila Tserkva (in Ukrainian).

Proster, L., \& Braun, F. (1996). Sravnitel'naya psikhologiya zhivotnykh. M.: Vyssh. shk. (in Russian).

Savel'yev, S. V. (1998). Vvedeniye v zoopsikhologiyu (fizicheskiye faktory kontrolya povedeniya, evolyutsiya polovogo povedeniya). M.: Area, 170-184 (in Russian).

Severynovs'ka, O. V., Pakhomov, O. Y., \& Rybal'chenko, V. K. (2010). Etolohiya (osnovy povedinky tvaryn) Dnipro: DNU (in Ukrainian).

Slyusar, N. V., Koval'chuk, V. I., \& Slyusarenko, Y. L. (2017). Istoriya formuvannya etolohiyi yak nauky pro povedinku tvaryn. Tvarynnytstvo ta henetyka, 53, 190-196. doi: 10.31073/abg.53.26 (in Ukrainian).

Southwood, T. R. E., \& Henderson, P. A. (2000). Ecological methods. Oxford: Wiley-Blackwell.

Tinbergen, N. (2012) Mir serebristoy chayki. M., ASTpress (in Russian).

Vagner, V. A. (2001). Psikhologiya razmnozheniya i evolyutsiya (genezis i evolyutsiya polovogo instinkta u zhivotnykh i cheloveka). Khrestomatiya po sravnitel'noy psikhologii i zoopsikhologii. Pod red. G.V. Kalyaginoy. SPb.: Piter, 156-202 (in Russian). 
Vagner, V. A. (2002). Izbrannyye trudy po zoopsikhologii (Psikhologicheskaya priroda instinktov, genezis instinkta po dannym biologii, instinkt i razum $\mathrm{v}$ ikh vzaimootnosheniy). M.: Nauka, 88-145 (in Russian).

Vanselow, K. H., Jacobsen, S., Hall, C. \& Garthe, S. (2017). Solar storms may trigger sperm whale strandings: explanation approaches for multiple strandings in the North Sea in 2016. Int. J. Astrobiol., 17(4), 336-344. doi: 10.1017/S147355041700026X.

Vladimirova, E. D. (2010). Psikhologiya zhivotnykh: Uchebnoye posobiye Samara: "Samarskiy universitet" (in Russian).
Zakon Ukrayiny (2006). Pro zakhyst tvaryn vid zhorstokoho povodzhennya: № 3447-IV. Vidomosti Verkhovnoyi Rady Ukrayiny. № 27. St. 230 (in Ukrainian).

Zorina, Z. A., \& Poletayeva, I. I. (2003). Zoopsikhologiya. Elementarnoye myshleniye u zhivotnykh (sravnitel'naya psikhologiya i zoopsikhologiya v Rossii, opisaniye "insayta" v opytakh V. Kelera. M.: Aspekt Press, 32-40 (in Russian). 